\title{
THE USAGE OF SOCIAL MEDIA IN DESTINATION MARKETING: A RESEARCH ON CITTASLOW IN TURKEY
}

\author{
Samet Çevik ${ }^{1}$
}

\begin{abstract}
Cittaslow movement as a local development model has become increasingly important all over the world since 1999. One of the important factor for the sustainability of this movement is communicated with both local residents and destination visitors accurately and conscious way about the principles and the benefits of Cittaslow philosophy and the unique features of the destination. At this point, social media is a key tool in destination marketing for Cittaslow destinations due to its features such as providing a competitive advantage, reaching a global audience, rapid dissemination of information, communicating with consumers. In this regard the study focuses the role of social media in destination marketing. The aim of the research is to determine how and at what level Cittaslow in Turkey use social media in destination marketing. In accordance with this purpose, content analysis technique was used and Facebook was chosen as social media channel. Among 11 Cittaslow in Turkey, 7 Cittaslow destinations (Gökçeada, Halfeti, Perşembe, Seferihisar, Şavşat, Vize, Yalvaç) that have an official municipality Facebook page were included to the research. This destinations' posts between January 2016 and June 2016 were analysed in terms of content, frequency and interactivity by utilising the categories Hays et al. (2013) created in their study. The findings of this study show that, Seferihisar Municipality uses social media more effectively in terms of content and post frequency but they also reveal that interactivity which is one of the most important features of social media is not adequately heeded by all Cittaslow destinations in Turkey.
\end{abstract}

Key words: Destination Marketing, Social Media, Facebook, Cittaslow, Turkey

\section{INTRODUCTION}

Social media which is identified the modus operandi of the $21^{\text {st }}$ century (Lange-Faria and Elliot, 2012: 193) plays a significant role in the information search and social media channels influence travel decisions. It is important for destinations to have an active official social media pages in their destination marketing exercises.

In the literature of destination marketing, there are many studies related to usage of social media both consumers' and suppliers' perspectives. Leung et al. (2013) found that, tourism and hospitality research on social media generally paid more attention to suppliers' application of social media. Supplier-related studies concentrated closely on promotion, management and research functions. In the literature any study could not be found about social media usage among Cittaslow destinations although Cittaslow movement's increasing popularity. By focusing on social media usage in destination

\footnotetext{
${ }^{1}$ Assistant Professor, Department of Tourism and Hotel Management, Erdek Vocational School, Bandırma Onyedi Eylül University, Erdek/Balıkesir, Turkey.
} 
marketing exercises, this study was conducted on the basis of Cittaslow destinations and aimed to fill this gap in the literature.

In the study, firstly the usage of social media in destination marketing was mentioned and then the information about the Cittaslow movement was presented. It was mentioned about the aim and the philosophy of the Cittaslow movement which started in Italy in 1999 and spread rapidly overtime and the criteria that must be fulfilled in order to participate in this network. Cittaslow movement is now represented in 30 countries and one of these countries, Turkey, has 11 Cittaslow as of 2016. In the study, by analyzing the official municipal Facebook pages of these Cittaslow destinations with a quantitative approach, it was tried to explore at what level Cittaslow destinations use social media.

\section{SOCIAL MEDIA AND DESTINATION MARKETING}

Social media is a group of Internet-based applications that build on the ideological and technological foundations of Web 2.0 and that allow the creation and exchange of user generated content (Kaplan and Haenlein, 2010: 61). Social media encompasses social networking sites (Facebook, MySpace), creativity works sharing sites (Youtube, Instagram, Flickr), business networking sites (LinkedIn), user sponsored blogs, company sponsored websites/blogs and chat rooms, collaborative websites (Wikipedia), virtual worlds (Second Life), commerce communities (eBay, Amazon.com) and numerous social media outlets like this (Mangold and Faulds, 2009). New social media types are emerging day by day and social media usage is steadily increasing. According to the "Digital in 2016" report broadcasted by "We are Social" on January 2016, approximately one third of the world population uses social media and compared to the previous year, the number of social media users worldwide increased \%10. Facebook continues to dominate the global social platform rankings with more than 1.5 billion active accounts. The data about Turkey show that \%58 of total population (46.3 million) is active internet user and compared to the previous year, the number of internet users increased $\% 10$. According to the report, $\% 53$ of total population (42 million) is active social media user and compared to the previous year, the number of social media users increased $\% 5$. Facebook is the most widely used social media channel also in Turkey with \%32 (http://wearesocial.com/uk/special-reports/digital-in2016).

Social media has become an important tool for marketing activities. Yoo and Gretzel (2010) identified several areas that distinguishes social media marketing from traditional marketing. These areas are; customer relations (feedback from customers, online customer service, virtual communities, real-time communication), product (value-added info on products via pictures, video etc., product customization, cocreation with consumers), price (flexible pricing, online payment), promotion (online promotions, customized promotion messages, customer participation), place (real time ordering and processing, online distribution of products), research (real time info, email 
alerts, free data, immediate reaction, multiple formats), performance measurement (conversations, continuous, consumer sentiment). Kaplan and Haenlein (2010) provide a set of recommendations to firms about social media for marketing activities in their study. These recommendations are into two sections: five points about using media and five points about being social. One of the five points about social media is choosing carefully the social media application according to target group. The next decision is about to join an existing social media application or launch its own social network. The third point is about aligning all social media activities with each other if the firm uses different types of applications. Another important point is integration of social media and traditional media. Finally the fifth point is accessing applications by all employees of the firm. Five points about being social are being active, being interesting, being humble, being unprofessional and being honest.

Social media has also become important for destination marketing activities. Xiang and Gretzel (2010) revealed that social media constitutes a substantial part of the online tourism domain and play an important role within the context of trip planning using a search engine. Consumers benefit by receiving what they perceive as more authentic information based on the experience of other travellers and can design their trips to reflect more closely what they are looking for by interacting with both experienced travellers and residents of a destination. On the other hand, destination marketing organizations can collaborate and streamline their information, adding value for consumers, while building their brand through direct interaction with the consumer and immediate response to consumers (Lange-Faria and Eliot, 2012: 204).

There are many studies in the literature about social media usage in destination marketing activities and social media strategies adopted by destinations. In one of these studies; Stankov, Lazić and Dragicevic (2010) found that half of NTOs in Europe do not have an official presence on Facebook. Likewise, Mariani et al. (2016) tried to explore how Italian DMOs strategically employ Facebook to promote and market their destinations and Yayli et. al (2011) carried out a study in order to explore how European DMOs use Twitter for marketing purposes. In another study, Hays et al. (2013) searched out the usage of social media among the DMOs of the top 10 most visited countries. One important finding revealed from the study is social media is not still an effective marketing tool for many DMOs. In a similar way, Yang and Wang (2015) explored ten DMOs' marketing strategies and outcomes in the social media channels in China. They found that among three kinds of social media channels (microblogs, social networking sites and mobile social applications) micro-blogs are the preferred social media marketing tool for most DMOs. Alizadeh and Isa (2015) researched social media usage of 193 countries' National Tourism Organizations (NTOs). They revealed that many NTOs are not aware of potential and opportunities offered by social media. Another important result of their study is the determination of Facebook as the top social media application used by NTOs. 
Although there are many studies about social media usage in destination marketing on a national and international basis, any study could not be found related to Cittaslow destinations' social media usage.

\section{CITTASLOW MOVEMENT}

The Cittaslow movement was born in 1999 as a local development model. The movement's philosophy is looking for the best of the knowledge of the past and enjoying it thanks to the best possibilities of the present and of the future. The motto of Cittaslow is "International network of cities where living is good" (http://www.cittaslow.org/content/philosophy). The aim of the Cittaslow movement is to help towns threatened by depopulation to raise the quality of life for the inhabitants and to create more visitor friendly destinations. Its main focus is on cultural heritage, to preserve and develop architecture and other traditional elements in destinations (Nilsson et al., 2011: 375). It emphasises the concept of good living in terms of quality of the local environment and gastronomic resources and the use of new technologies for collective well-being (Miele, 2008: 137). Promoting local distinctiveness and a sense of place is almost as important to the movement as the enjoyment of local gastronomic resources. Candidate cities must be committed not only to supporting traditional local arts and crafts but also to supporting modern industries whose products lend distinctiveness and identity to the region (Knox, 2005: 6).

For a city to become a Cittaslow member, the population must number less than 50.000 and comply with a list of criteria set by the association (Heitmann et al., 2011). These criteria were updated from 1999 to the present day. For example; as Heitmann et. al mentioned in their study, in 2006 there were 55 criteria in 6 mean headings. This number increased to 59 in the following years. New criteria have been added for being Cittaslow membership in the Cittaslow International Regulation published on June 21, 2014. Totally 72 criteria are laid out under seven headings. These headings are (http://www.cittaslow.org/content/how-become):

$>$ Energy and Environmental Policies (12 criteria): Parks and green areas, renewable energy, transport, recycling etc.

$>$ Infrastructure Policies (9 criteria): Alternative mobility, cycle paths, street furniture etc.

$>$ Quality of Urban Life Policies (17 criteria): Requalification and reuse of marginal areas, cable network city etc.

$>$ Agricultural, Touristic and Artisan Policies (10 criteria): Prohibiting the use of GMO in agriculture, increasing the value of working techniques and traditional crafts etc.

$>$ Policies for Hospitality, Awareness and Training (10 criteria): Good welcome, increasing awareness of operators and traders etc.

$>$ Social Cohesion (11 criteria): Integration of disabled people, poverty, minorities discriminated etc. 
> Partnerships (3 criteria): Collaboration with other organizations promoting natural and traditional food etc.

There are no criterion directly related to social media in the criteria but it is emphasized that integrating technologies and particularly internet is very important for Cittaslow movement. Social media offers a number of advantages for Cittaslow destinations. First of all, social media is an effective way to communicate with local residents about Cittaslow movement's philosophy and principles. Thus, the pride feelings of local residents about their city and level of awareness related to core values of the city increase. Social media can make destination more attractive. Unique local features that make up the identity of the destination can be introduced appealingly to potential visitors via social media. Thanks to the interactivity feature of social media, both local residents and visitors can come together under Cittaslow umbrella.

There are 222 Cittaslow in 30 countries all over the world. In Turkey, there are 11 Cittaslow. Seferihisar achieved the first Cittaslow certification in 2009 and Seferihisar describes itself as the capital of Cittaslow in Turkey. In 2011, four more cities Akyaka, Yenipazar, Gökçeada and Taraklı - achieved the Cittaslow certification. In 2012, the number of Cittaslow in Turkey reached 8 with Yalvaç, Vize and Perşembe. In the following year Halfeti, in 2015 Şavşat and finally Uzundere joined the Cittaslow network.

\section{METHODOLOGY}

In this section, information on research aim, research method, research population, data gathering and analysis is presented.

\section{Aim of the Research}

The aim of the research is to determine how and at what level Cittaslow in Turkey use social media in destination marketing. For this purpose, the study seeks to answer these following questions:

$>$ How often do Cittaslow destinations in Turkey post on their social media pages?

$>$ What is the level of interaction with their followers?

$>$ What are the contents of their posts?

\section{Research Method}

The research is exploratory - it focuses to reveal how Cittaslow destinations in Turkey use social media for destination marketing. To reveal this content analysis was used in the study. Content analysis is a research technique for the objective, systematic and quantitative description of the manifest content of communication (Berelson, 1952: 8 as cited in Neuendorf, 2002: 10). The study makes a quantitative expression about the 
usage of social media by Cittaslow destinations. Facebook was chosen as a social media channel in the study, because as mentioned in previous chapters, it is the most preferred social media channel both in the world and in Turkey.

\section{Research Population}

The research population is 11 Cittaslow in Turkey. Cittaslow Akyaka and Cittaslow Taraklı have no an official Facebook page. Cittaslow Yenipazar has an official page but it is not active. The last post was on January 2014. Cittaslow Uzundere has a Facebook account as a person page, not an official page. So, 7 Cittaslow in Turkey (Gökçeada, Halfeti, Perşembe, Seferihisar, Şavşat, Vize and Yalvaç) were included to the research.

\section{Data Gathering and Analysis}

7 Cittaslow destinations' Facebook posts between 1 January 2016 and 30 June 2016 were analysed. These official Facebook pages' links and their number of followers as of 30 June 2016 can be seen from Table 1.

Table 1. Official Facebook Links and Number of Followers

\begin{tabular}{|l|l|l|}
\hline & Official Facebook Links & Followers \\
\hline Gökçeada & $\begin{array}{l}\text { (https://www.facebook.com/Gökçeada-Belediyesi- } \\
1407361359572908 /)\end{array}$ & 2811 \\
\hline Halfeti & https://www.facebook.com/halfetibelediyesi & 4987 \\
\hline Perşembe & https://www.facebook.com/sakinpersembe52 & 2486 \\
\hline Seferihisar & $\underline{\text { https://www.facebook.com/shisarbel }}$ & 8135 \\
\hline Şavşat & https://www.facebook.com/savsatbelediye/ & 3375 \\
\hline Vize & $\underline{\text { https://www.facebook.com/VizeBelediyesi }}$ & 5577 \\
\hline Yalvaç & $\underline{\text { https://www.facebook.com/belediyeyalvac }}$ & 4526 \\
\hline
\end{tabular}

The analyzes were carried out in July and August 2016 in terms of post frequency, interactivity and content based on the categories Hays et al. (2013) created in their study. These categories can be seen from Table 2 .

Table 2. The Categories for Content Analysis

\section{INTERACTIVITY}

\begin{tabular}{l|l|l|}
$\begin{array}{l}\text { Are there likes, comments and } \\
\text { shares? }\end{array}$ & \multicolumn{2}{|c}{ Is the post customer service related? } \\
$>$ How many likes? & $>\quad$ Is it responding to criticism? \\
$>$ How many comments and replies? & $>$ Is it thanking customers/travellers?
\end{tabular}




\begin{tabular}{|c|c|}
\hline$>$ How many shares? & $\begin{array}{l}>\text { Is it requesting feedback from } \\
\text { customers/travellers? } \\
>\text { Is it responding to an enquiry? }\end{array}$ \\
\hline $\begin{array}{l}\text { Is the post contest related? } \\
>\quad \text { Is it asking a trivia question? } \\
>\quad \text { Is it providing the answer to a trivia }\end{array}$ & \\
\hline $\begin{array}{l}\text { question? } \\
\text { Is it reminding users of an on-going } \\
\text { contest? } \\
\text { Is it announcing winners of a trivia } \\
\text { question or contest? }\end{array}$ & $\begin{array}{l}\text { Does the post request user-generated } \\
\text { content? } \\
>\quad \text { Is it requesting photos? } \\
>\quad \text { Is it requesting videos? } \\
\text { Is it requesting audio? }\end{array}$ \\
\hline
\end{tabular}

\section{CONTENT}

\section{Does the post include additional content? \\ $>$ Does it include a link to a website? \\ $>$ Does it include a photo? \\ $>$ Does it include a video?}

\section{Does the post provide information?}

$>$ Does it provide factual information? (e.g. dates or location of an event, announcements)

$>$ Does it provide opinion or review? (e.g. the best places to visit)

$>$ Does it provide information about the municipality's services or newsworthy visits, meetings or activities? (e.g. infrastructure works, visits of the Mayor, opening ceremonies etc.)

General - the post does not fit any particular categories (e.g. Happy weeks, blessings or wishes, special day celebration messages etc.)

\section{Is the post promotion related?}

$>$ Is it promoting a touristic event?

$>$ Is it promoting a destination?

$>$ Is it promoting another website?

$>$ Is it promoting the destination's official website?

$>$ Is it promoting an attraction of the destination?

Is it promoting a local food?

$>$ Is it promoting another social media channel of the destination?

\section{Does the post include Cittaslow content?}

$>$ Do the photos include Cittaslow logo?

$>$ Does the post include 'Cittaslow' expression? (e.g. Good morning to everyone from Cittaslow Seferihisar?)

$>$ Does the post directly related to Cittaslow movement?

Has the information in the post or the post been posted previously?

The information or the post has been posted previously by the page itself.

The information or the post has been posted previously by another page or user.

Adapted from Hays et al. (2013) 


\section{RESEARCH FINDINGS}

Findings of the research are presented under three headings: Post Frequency, Interactivity and Content.

\section{Post Frequency Findings}

Table 3 shows total number of posts and average number of daily posts. Seferihisar has more posts and it is the only Cittaslow that exceeds daily 1 post.

Table 3. Average Number of Daily Posts and Total Number of Posts

\begin{tabular}{|l|l|l|l|l|l|l|l|l|}
\hline & Jan. & Feb. & Mar. & Apr. & May & June & TOTAL & \multicolumn{2}{l|}{} \\
\hline & & & & & & & $\begin{array}{l}\text { Total } \\
\text { Number } \\
\text { of Posts }\end{array}$ & $\begin{array}{l}\text { Number of } \\
\text { Posts }\end{array}$ \\
\hline Gökçeada & 18 & 21 & 18 & 29 & 25 & 28 & 139 & 0,76 \\
\hline Halfeti & 7 & 15 & 14 & 8 & 8 & 28 & 80 & 0,43 \\
\hline Perşembe & 12 & 9 & 4 & 13 & 3 & 0 & 41 & 0,22 \\
\hline Seferihisar & 22 & 11 & 27 & 47 & 48 & 43 & 198 & 1,08 \\
\hline Şavşat & 27 & 11 & 17 & 25 & 25 & 25 & 130 & 0,71 \\
\hline Vize & 7 & 9 & 42 & 22 & 35 & 29 & 144 & 0,79 \\
\hline Yalvaç & 10 & 11 & 26 & 32 & 32 & 31 & 142 & 0,78 \\
\hline
\end{tabular}

\section{Interactivity Findings}

Interactivity means a post that directly asks a question, requests feedback or input from the followers (Hays et al., 2013). The findings show that none of 7 Cittaslow destinations' posts are related to customer service or a contest and none of them are requested user generated contents. "Likes", "Comments" and "Shares" are also a way of customer interaction. Table 4 shows degree of consumer interaction with "likes". Except Perşembe, all the posts of other destinations have likes at least one. According to average number of "likes", it can be said that Vize, Seferihisar and Yalvaç are more interactive.

Table 4. Degree of Consumer Interaction with "Likes"

\begin{tabular}{|l|l|l|l|l|}
\hline & $\begin{array}{l}\text { Total } \\
\text { Number } \\
\text { of Posts }\end{array}$ & $\begin{array}{l}\text { \% of posts } \\
\text { "Liked" }\end{array}$ & $\begin{array}{l}\text { Total Number } \\
\text { of "Likes" }\end{array}$ & $\begin{array}{l}\text { Average Number } \\
\text { of "Likes" per } \\
\text { post }\end{array}$ \\
\hline Gökçeada & 139 & 100 & 9030 & 64,96 \\
\hline Halfeti & 80 & 100 & 5735 & 71,68 \\
\hline Perşembe & 41 & 95,12 & 255 & 6,21 \\
\hline Seferihisar & 198 & 100 & 17845 & 90,12 \\
\hline
\end{tabular}




\begin{tabular}{|l|l|l|l|l|}
\hline Şavşat & 130 & 100 & 8452 & 65,01 \\
\hline Vize & 144 & 100 & 13644 & 94,75 \\
\hline Yalvaç & 142 & 100 & 12369 & 87,10 \\
\hline
\end{tabular}

Total number of comments and shares can be seen from Table 5. Seferihisar and Yalvaç have more comments and Seferihisar and Vize have more shares.

Table 5. Degree of Consumer Interaction with "Comments" and "Shares"

\begin{tabular}{|l|l|l|l|l|}
\hline & $\begin{array}{l}\text { Total Number } \\
\text { of Posts } \\
\text { Commented }\end{array}$ & $\begin{array}{l}\text { Total } \\
\text { Number of } \\
\text { Comments }\end{array}$ & $\begin{array}{l}\text { Total Number } \\
\text { of Posts Shared }\end{array}$ & $\begin{array}{l}\text { Total } \\
\text { Number of } \\
\text { Shares }\end{array}$ \\
\hline Gökçeada & 46 & 98 & 61 & 237 \\
\hline Halfeti & 35 & 80 & 51 & 363 \\
\hline Perşembe & 10 & 24 & 8 & 13 \\
\hline Seferihisar & 100 & 453 & 170 & 5454 \\
\hline Şavşat & 54 & 132 & 84 & 1491 \\
\hline Vize & 51 & 134 & 114 & 3223 \\
\hline Yalvaç & 69 & 354 & 113 & 1514 \\
\hline
\end{tabular}

Followers may criticise or ask questions about the events or services of destination by commenting the posts. Replying the comments for an official page is vital for interact the customers. In the study findings revealed that Seferihisar replied \%6,84 of 453 comments, Şavşat replied \%2,27 of 132 comments, Halfeti replied \%1,25 of 80 comments. They also revealed that other destinations did not reply any comment.

\section{Content Findings}

The Content heading was evaluated based on the following categories: Additional content, information content, promotion content, Cittaslow content, general content and originality.

Figure 1 shows whether the posts have additional content - photo, web site link or video. All destinations' posts have photos in high quantity. The posts of Şavşat have more web site links. But all destinations have a very low rate in terms of video content. 


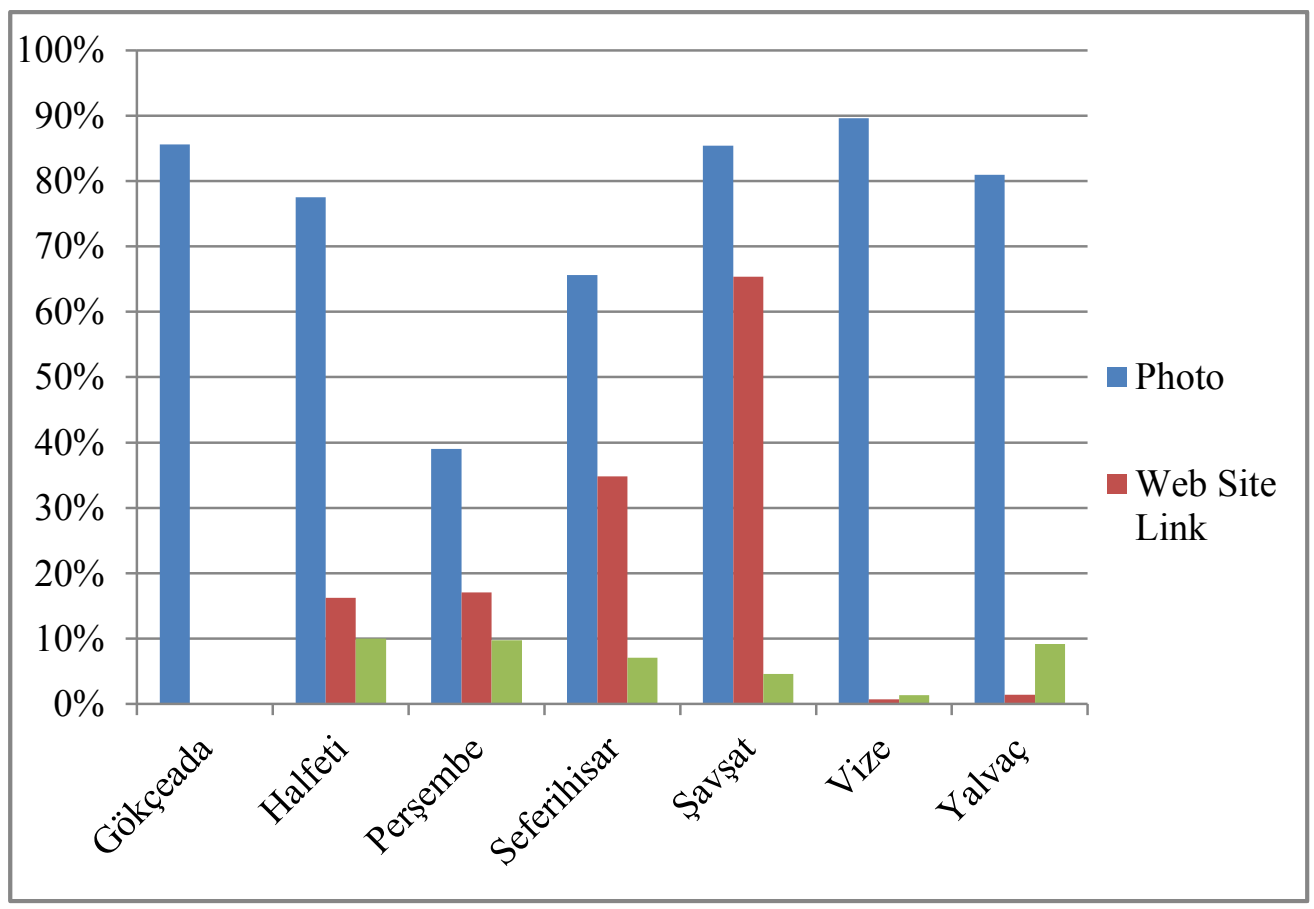

Figure 1. Additional Content

Promotion content includes promoting a touristic event, the destination, another website, the destination's official website, an attraction of the destination, a local food and another social media channel of the destination.

Cittaslow Seferihisar has 24 posts $(\% 12,12)$ related to promotion content. 7 of these posts are about promoting an attraction, 5 of these are about promoting a touristic event, 5 of these are about promoting the destination, 4 of these are about promoting another website, 2 of these are promoting the official website and 1 post is about promoting a local food. Cittaslow Şavşat has 14 posts $(\% 10,76)$ related to promotion content. 8 of these posts are about promoting the destination, 3 of these are promoting a touristic event, 2 of these are promoting an attraction and 1 post is about promoting another social media channel. Cittaslow Perşembe has 11 posts $(\% 26,82)$ related to promotion content. 8 of 11 posts are related to another social media channel (Mayor's official Facebook page). Cittaslow Halfeti has 4 posts (\% 5), Cittaslow Yalvaç has 4 posts $(\% 2,81)$, Cittaslow Vize has 2 posts $(\% 1,38)$ and Cittaslow Gökçeada has 1 post $(\% 0,71)$ related to promotion content.

Information content includes providing factual information, information about services or activities of the municipality and opinion or review. Figure 2 shows the findings of information content. Majority of posts of all destinations provide information about services or activities of the municipality. 


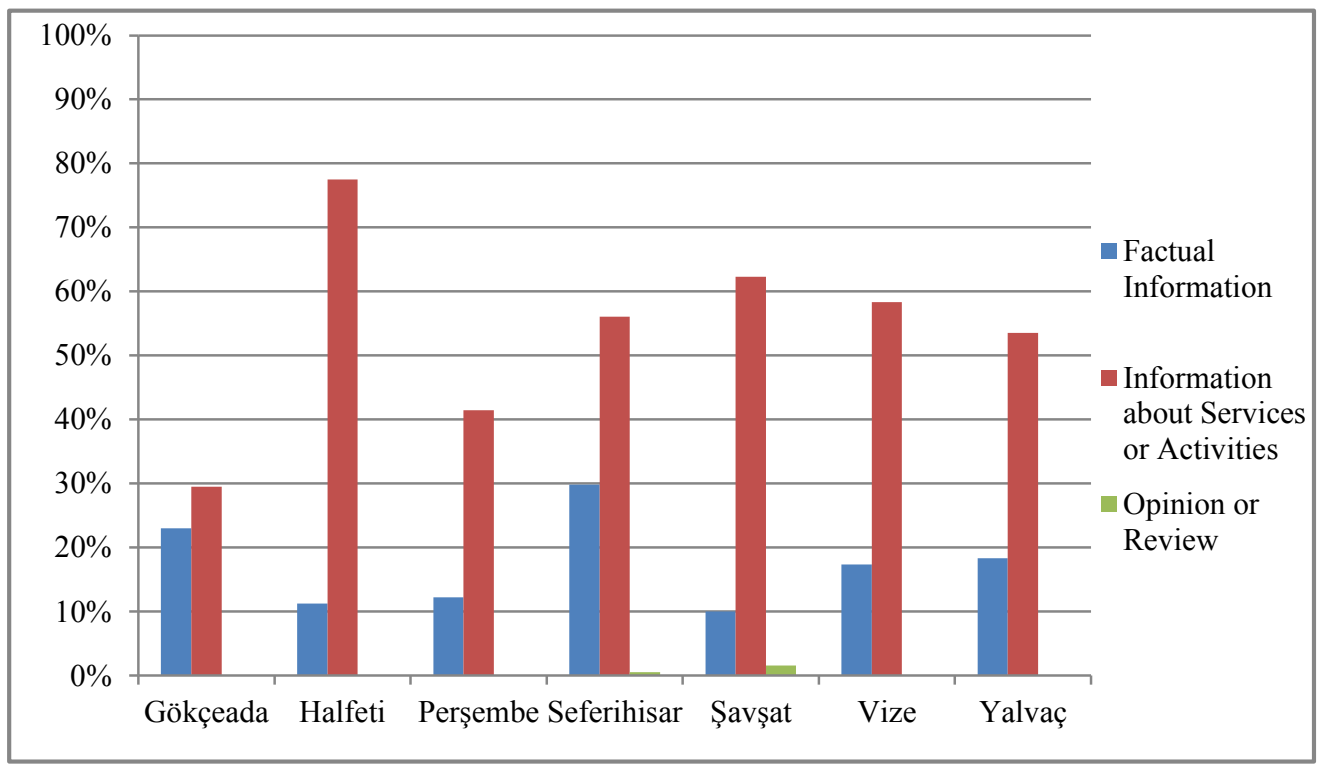

Figure 2. Information Content

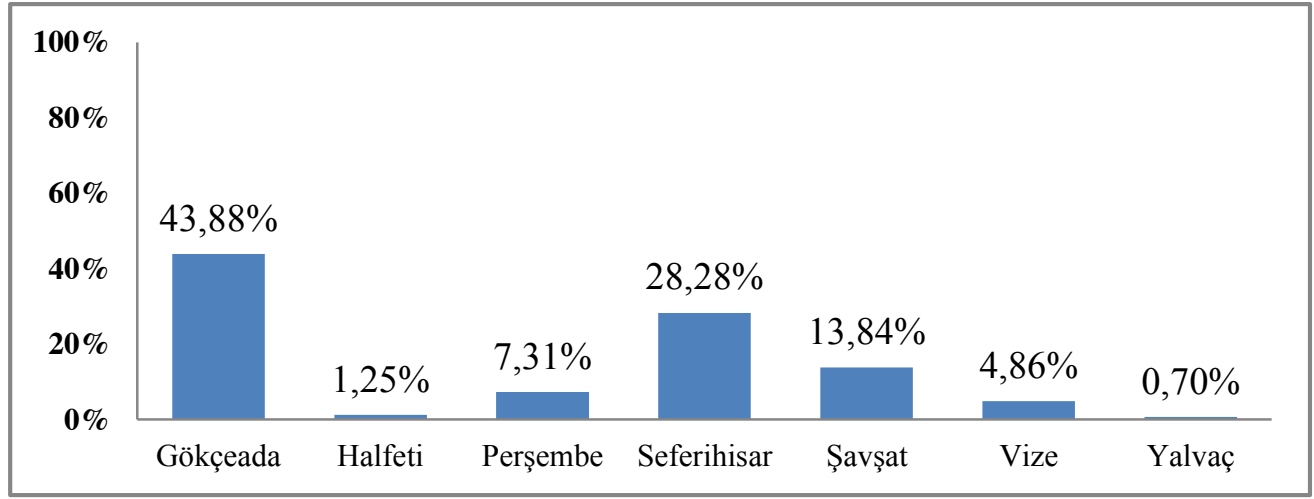

Figure 3. Cittaslow Content

Cittaslow content is about whether the posts have Cittaslow logo and Cittaslow expression or whether the posts are directly related to Cittaslow movement. The findings show that Cittaslow Gökçeada and Cittaslow Seferihisar have more posts related to Cittaslow content. It was revealed that other destinations didn't use very much the Cittaslow label in their posts. The results can be seen more clearly from Figure 3. General content includes posts that does not fit any other category. For example; good morning, happy weeks or special day celebration messages. As can be seen in Figure 4, Cittaslow Gökçeada has more posts related to general content. 


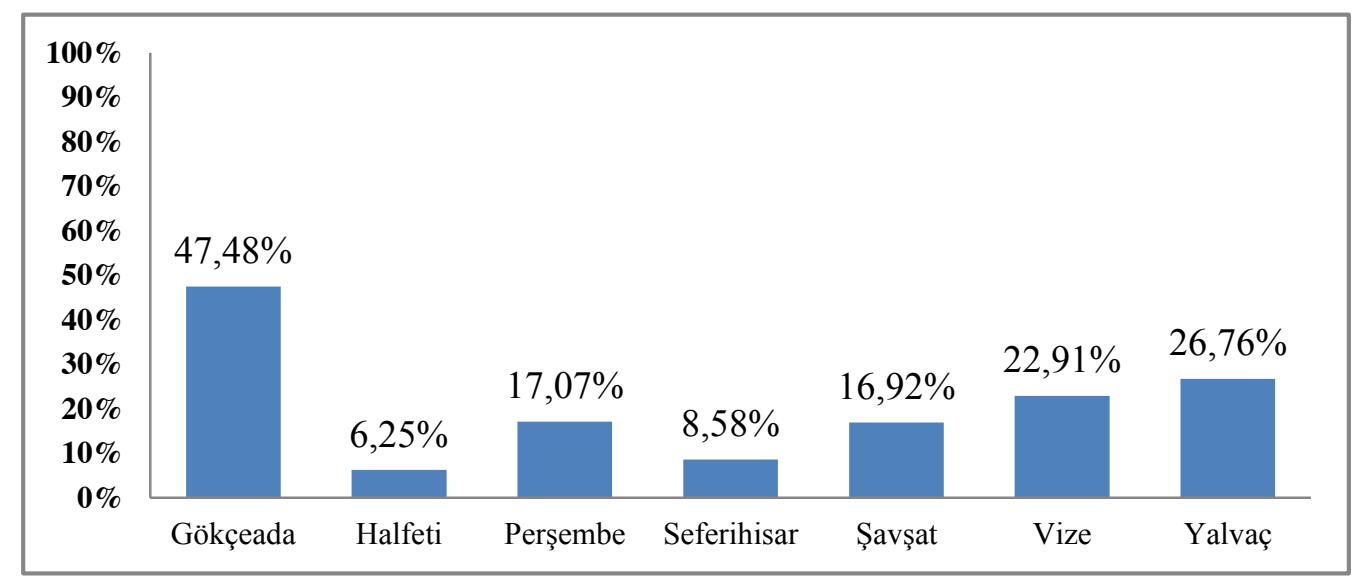

Figure 4. General Content

"Originality" is about whether the post was shared previously. Originality levels of posts are very high in Cittaslow Halfeti, Cittaslow Seferihisar, Cittaslow Şavşat and Cittaslow Vize. Table 6 shows the originality levels of posts.

Table 6. Originality Levels of Posts

\begin{tabular}{|l|l|l|l|l|}
\hline & $\begin{array}{l}\text { Posted previously } \\
\text { by the page itself }\end{array}$ & $\begin{array}{l}\text { Posted previously } \\
\text { by another page }\end{array}$ & \multicolumn{2}{l|}{ Original } \\
\hline Gökçeada & 35 posts & 2 posts & 102 posts & $\% 73,88$ \\
\hline Halfeti & - & 2 posts & 78 posts & $\% 97,50$ \\
\hline Perşembe & 4 posts & 5 posts & 22 posts & $\% 53,65$ \\
\hline Seferihisar & 8 posts & 11 posts & 189 posts & $\% 95,45$ \\
\hline Şavşat & 3 posts & 1 post & 126 posts & $\% 96,92$ \\
\hline Vize & 4 posts & 2 posts & 138 posts & $\% 95,83$ \\
\hline Yalvaç & 4 posts & 13 posts & 125 posts & $\% 88,02$ \\
\hline
\end{tabular}

\section{CONCLUSION}

This study contributes to the literature in terms of providing concrete data on social media usage of Cittaslow destinations. There is not much research in the literature on the use of Internet and social media on the basis of Cittaslow movement. But social media is important for Cittaslow destinations in the efforts of destination marketing by using Cittaslow label. The results of this study show that, similar to the study of Hays et al. (2013), social media is not yet an effective tool for Cittaslow in Turkey.

Among 7 Cittaslow destinations, Cittaslow Seferihisar has the highest post frequency percentage. Except Perşembe and Halfeti, other destinations have average post frequency level. The findings of study show that all destinations ignore the power of social media called "interactivity". The feature of interactivity differentiate destination marketing from traditional methods and a destination which interacts its customers via 
social media gains competitive advantage. Interacting customers - whether local residents or visitors - by replying their questions or criticisms and solving their problems, asking them questions about the destination or creating winning competitions on a small scale will increase their commitment to the destinations. All Cittaslow destinations have an additional content - especially photos - in many of their posts but it could be better to post more destination and Cittaslow oriented videos. Promotion and Cittaslow contents are quite poor for most of the destinations. In terms of promotion content, it can be said that Seferihisar and Şavşat share different types of posts but it is not sufficient as quantity. It was revealed that Cittaslow label is not emphasized by many Cittaslow destinations in destination marketing.

Similar to the result of the study of Alizadeh and Isa (2015), Cittaslow destinations are still not aware of potential and opportunities offered by social media and for those with social media presence, there is a great room for improvement in strategic use of social media. Cittaslow destinations should understand the power of social media and should make arrangements in their destination marketing strategies to use this power. They can work with social media experts or buy a professional social media consultancy service. It could be better to have a Facebook page with the name of "Cittaslow" as a government organisation page as well as official municipal page. There are Cittaslow Şavşat, Cittaslow Vize, Cittaslow Uzundere and Cittaslow Perşembe pages as government organisation pages like that but they are not active as municipal pages. By using social media pages as efficiently as possible, Cittaslow destinations should clarify the principles and benefits of Cittaslow movement to local residents and should promote their awareness in the eyes of potential visitors.

\section{LIMITATIONS AND FUTURE STUDIES}

This study was conducted to explore the level of social media usage of Cittaslow destinations and does not present findings on social media strategies of these destinations. In future studies, qualitative researches can be carried out to explore viewpoint to social media and social media strategies of these destinations. Moreover, comparative studies can be conducted related to social media usage of Cittaslow destinations of different countries.

\section{REFERENCES}

1. Alizadeh, A., \& Isa, R. M. (2015). The Use of Social Media in Destination Marketing: An Exploratory Study. Turizam: Znanstveno-Stručni Časopis, 63(2), 175-192.

2. Hays, S.; Page, S. J. and Buhalis, D. (2013). Social Media as a Destination Marketing Tool: Its Use by National Tourism Organisations. Current Issues in Tourism, 16(3), 211-239. 
3. Heitmann, S.; Robinson, P. and Povey, G. (2011). Slow Food, Slow Cities and Slow Tourism. P. Robinson, S. Heitmann and P. Dieke (Ed.), Research Themes for Tourism, 114-127, UK: CAB International.

4. Kaplan, A. M. and Haenlein, M. (2010). Users of the World, Unite! The Challenges and Opportunities of Social Media. Business Horizons, 53, 59-68.

5. Knox, P. L. (2005). Creating Ordinary Places: Slow Cities in a Fast World. Journal of Urban Design, 10(1), 1-11.

6. Lange-Faria, W. and Elliot, S. (2012). Understanding the Role of Social Media in Destination Marketing. Tourismos: An International Multidisciplinary Journal of Tourism, 7(1), 193-211.

7. Leung, D.; Law, R.; van Hoof, H. and Buhalis, D. (2013). Social Media in Tourism and Hospitality: A Literature Review. Journal of Travel \& Tourism Marketing, 30(1-2), 3-22.

8. Mangold, W. G. and Faulds, D. J. (2009). Social Media: The New Hybrid Element of the Promotion Mix. Business Horizons, 52, 357-365.

9. Mariani, M. M.; Felice, M. D. and Mura, M. (2016). Facebook as a Destination Marketing Tool: Evidence From Italian Regional Destination Management Organizations. Tourism Management, 54, 321-343.

10. Miele, M. (2008). Cittaslow: Producing Slowness Against the Fast Life. Space and Polity, 12(1), 135-156.

11. Neuendorf, K. A. (2002). The Content Analysis Guidebook. California: Sage Publications.

12. Nilsson, J. H.; Svärd, A. C.; Widarsson, Å. and Wirell, T. (2011). 'Cittaslow' EcoGastronomic Heritage as a Tool for Destination Development. Current Issues in Tourism, 14(4), 373-386.

13. Stankov, U.; Lazić, L. and Dragicevic, V. (2010). The Extent of Use of Basic Facebook User-Generated Content by the National Tourism Organizations in Europe. European Journal of Tourism Research, 3(2), 105-113.

14. Xiang, Z. and Gretzel, U. (2010). Role of Social Media in Online Travel Information Search. Tourism Management, 31, 179-188.

15. Yang, X. and Wang, D. (2015). The Exploration of Social Media Marketing Strategies of Destination Marketing Organizations in China. Journal of China Tourism Research, 11(2), 166-185.

16. Yayl1, A.; Bayram, M. and Bayram, Ü. (2011). How Social Media Works in Destination Marketing? A Content Analysis on Twitter. $10^{\text {th }}$ International Marketing Trends Congress. 20-22 June, Paris, France.

17. Yoo, K. H. and Gretzel, U. (2010). Web 2.0: New Rules for Tourism Marketing. $41^{\text {st }}$ Travel and Tourism Research Association Conference, 20-22 June, San Antonio, Texas, USA.

18. http://wearesocial.com/uk/special-reports/digital-in-2016

19. http://www.cittaslow.org/content/philosophy

20. http://www.cittaslow.org/content/how-become 